\title{
IMPACTS OF COVID-19 PANDEMIC ON AGRICULTURE, FOOD PRICES, AND FOOD SECURITY IN MOROCCO
}

\author{
ET-TOUILE Houria ${ }^{1}$, ARIB Fatima ${ }^{2}$ \\ 1. PhD student in economic sciences/Laboratory "Innovation, Responsibilities and sustainable \\ development", Cadi Ayad University, Marrakech, Morocco \\ 2. Professor of Higher Education, Director of National School of Business and Management of \\ Marrakech, Cadi Ayad University of Marrakech, Morocco
}

\begin{abstract}
With the global health crisis related to the new coronavirus pandemic (Covid-19), the thorny issue of food security has arisen with force, especially with shortages of certain products on the markets, soaring prices, and sometimes even stock-outs. The covid-19 pandemic has led to a global economic crisis that has called into question the stability ensuring global food security.

So, the present paper aims to analyze and discuss the impact of the Covid-19 pandemic on agriculture, food supply, and food security in Morocco. Toward this end, data provided by the Food Agriculture Organization (FAO), and the World Health Organization (WHO) have been analyzed, as well as studies conducted and published on the subject.

The findings indicate that the Covid 19 pandemic has ensued several negative effects, which have directly and indirectly threatened Moroccan food security. It severely affected the agricultural sector which contributes significantly to GDP, due to suspension of agricultural activities, restriction of trade in agricultural commodities, and agricultural labor. Also, It has primarily affected food imports due to the dependence on food importation and has impacted food supply chains, as the shutdown and closing of some stores severely disrupted the supply chain (transportation, storage, and distribution), resulting in food insufficiency in many far areas.

Globally, food security in Morocco has demonstrated its resilience during the Covid-19 pandemic, due to the agricultural strategy put in place, the market was regularly supplied and the availability of products was ensured in all the cities of the Kingdom. Finally, based on the findings, we have suggested some recommendations that would help boost sustainable food security.
\end{abstract}

Keywords: COVID 19, agriculture, food security, food prices, food systems, Morocco.

\section{Introduction}

The Covid-19 pandemic is a virus that appeared in Wuhan (China) at the end of 2019 and spread rapidly around the world. This pandemic has created an unprecedented global economic crisis by profoundly disrupting activities essential to human needs, such as agriculture and food systems, and threatening the 
livelihoods of people living on these activities. Morocco's economy is very affected by the economic and social repercussions of Covid-19.

On March 19, 2020, the Moroccan government declared a state of health emergency to stop the COVID19 pandemic. To prevent the spread of the virus, it implemented mitigation measures, including health, hygiene, social distancing, and movement restrictions in major cities.

Morocco, which has distinguished itself by the promptness of its response to the crisis at all levels, can be proud to be part of it. The pandemic has been a major challenge to the Kingdom's ability to adequately meet the food needs of the population. The course of events has revealed that agriculture and its industrial counterpart have the necessary resilience to face an eruptive situation, both in terms of productivity, organization, and logistics. Whether for fresh products (fruits and vegetables), meats, or industrial foodstuffs, essentially necessities, the markets remained supplied without interruption, even at the height of the wave of panic buying.

The Kingdom is reaping the fruit of strategic choices made for decades, which began with the visionary policy of dams in the early years of Independence and be strengthened in 2008 by the Green Morocco Plan (GMP), which brought agriculture into the era of modernization and massive private and public investment.

According to the FAO, the Covid-19 pandemic is a global one that is already hitting the food and agricultural sector. The disruption caused by the Covid-19 pandemic puts the food security of billions of people at risk. Food demand and therefore food security is affected due to movement constraints, low purchasing and a huge impact on the most vulnerable population groups, as cases increase, governments are taking effective and more comprehensive measures and procedures to curb the spread of disease. virus, and thus influenced the food system.

The consequences of the global covid-19 pandemic on the agricultural sector around the world require immediate long-term actions. It is necessary to analyze and understand the immediate consequences of the current pandemic on food and systems to develop the necessary actions, through the risks, the vulnerability, resilience, and changes in agricultural systems to adapt to the current situation need to be better understood.

Thereover, many studies have been conducted to corroborate and estimate the impact of the Covid-19 epidemic on agriculture (Kerr, 2020; Siche, 2020; Willy et al., 2020), food security (Deaton \& Deaton, 2020; Zurayk, 2020), grains, and oilseeds sector (Brewin, 2020), agrarian trade (Barichello, 2020), fruit and vegetable requests (Richards \& Rickard, 2020), dairy and flesh sectors (Weersink, 2020), food security in the Near East and North Africa (FAO, 2020a), agriculture, food security and animal sectors (Seleiman etal., 2020), consumer food demand responses (Cranfield, 2020). There's still a considerable 
exploration gap of studies examining the impact of Covid-19 on food security. Consequently, we try through this paper to answer the following question what's the impact of Covid-19 on agriculture, food prices, and food security in Morocco?

This paper aims to contribute to a better understanding of the linkages between COVID-19 on agriculture and food security and highlights the importance of integrated action for addressing the interconnected challenges for sustainable agriculture and food systems in Morocco.

\section{THE IMPACT OF COVID-19 ON MOROCCAN ECONOMIC GROWTH}

The Moroccan economy has suffered the disastrous consequences of the COVID-19 pandemic, experiencing in 2020 its first recession in more than two decades. Real GDP declined by 5.9 percent in 2020, after increasing by 2.5 percent in 2019. In addition to the adverse effects of a strict three-month containment to contain the spread of COVID-19, a drought also weighed on rural incomes, further reducing domestic demand. Economic growth depends on rainfall, which affects the agricultural sector. Unemployment increased from 9.2 percent at the end of 2019 to 12.7 percent at the end of September 2020.

Annual economic growth is the volume change in GDP according to the system of national accounts and is considered one of the main macroeconomic indicators since it measures the rate of increase of economic activity in the nation. Gross domestic product (GDP) is the synthetic result of national production activity. It represents the wealth created in the country's economic territory during the period under consideration. The variation of the national GDP during the last ten years is presented in figure 1 to have a clearer vision of its evolution.

Figure 1: Annual GDP growth in Morocco (in \%)

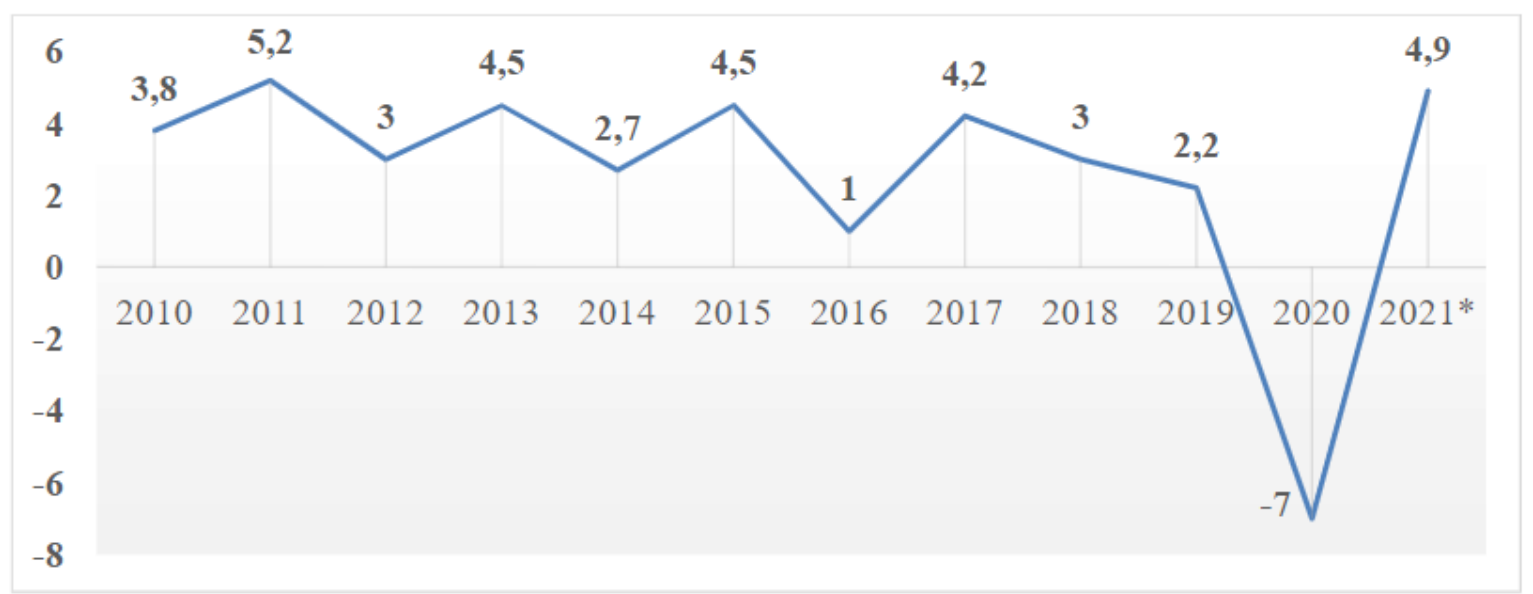

Source: IMF, World economic outlook (October 2020). 
Economic growth over the past ten years has been moderate but volatile, due to a large fluctuation in agricultural production, which currently accounts for nearly 13\% of Morocco's GDP. In 2020, the COVID-19 shock caused a GDP contraction of 7\%, more severe than that experienced by Morocco in 1995 (-5.4\%). The IMF forecasts a rebound in 2021, an upward trend in Moroccan GDP of 4.9\%. However, these forecasts are surrounded by a high degree of uncertainty due to the lack of visibility of the duration and extent of the crisis.

Disruptions in global value chains and a sudden slowdown in demand from Morocco's main trading partners (Spain, France, Italy, and Germany) have also reduced Moroccan exports, which fell by 10.1 percent in the first ten months of 2020. Over the same period, lower domestic production and consumer demand reduced imports by 16.6 percent. Workers' remittances increased by 1.7 percent in the first ten months of 2020. Nevertheless, the current account deficit is expected to widen from 4.1 percent in 2019 to 7.6 percent in 2020, mainly due to lower tourism receipts. Tourist arrivals fell by 78 percent in the first nine months of the year. The decline in tourism receipts, coupled with subdued domestic demand, has reduced tax revenues, while the government has incurred high pandemic-related expenditures. The budget deficit nearly doubled from 4.1 percent of GDP in 2019 to about 8 percent in 2020.

The need to finance the deficit has increased borrowing, raising public debt from 65.8 percent of GDP in 2019 to 76.9 percent in 2020. Public debt was already high before the pandemic, mainly due to borrowing to finance the government's ambitious infrastructure investment program over the past decade. Inflation is expected to remain low. On March 9, 2020, Moroccan authorities widened the fluctuation band for the dirham to increase the economy's ability to absorb external shocks and improve its competitiveness.

The central bank, Banque Al-Maghrib, has hardly intervened in the foreign exchange market despite lowering its key interest rate by 25 basis points in March 2020 and by another 50 basis points to 1.5 percent in June 2020. Over the past decade, Morocco has improved its position in the World Bank's Doing Business ranking by more than 50 places. In 2020, Morocco ranked 53rd out of 190 countries.

According to the HCP, economic growth did not exceed $0.1 \%$ in the first quarter of the year. This weak growth is attributed to the accentuation of the decline in agricultural value added to $-5 \%$ and the slowdown in industry and market services (HCP, 2020).

In the second quarter of 2020, the Moroccan economy, under strict population containment for nearly 10 weeks out of 13, faced a decline in domestic demand. Household consumption, in volume terms, is estimated to have declined by 6.7 percent. This decline would have affected, in particular, household 
spending on manufactured goods, especially clothing and equipment, as well as on transportation, restaurants, and recreation.

External demand would also have been weakened, leading to a $25.1 \%$ drop in the volume of exports. Imports, for their part, would have fallen by $26.7 \%$, impacted by the decline in purchases of capital goods, energy products, raw materials, and semi-finished and finished products. Under these conditions, the decline in GDP would have reached $-13.8 \%$ compared to the same period in 2019 (WB,2020).

By branch of activity, the decline in value-added would have been $-6.1 \%$ in the second quarter of 2020 , in agriculture, due to the drought. The tertiary sector, the main driver of economic growth, would have declined by $11.5 \%$, suffering from the contraction of commercial, transport, accommodation, and catering activities.

For the year 2020 as a whole, the Moroccan economy is expected to experience its first recession in more than two decades as a result of a combination of drought and the pandemic (Figure 1). In fact, according to the HCP's annual forecasts, GDP would contract by $5.8 \%$, accompanied by a widening of the budget deficit to $7.4 \%$ of GDP. The current account deficit is also expected to worsen to $6.9 \%$ of GDP (HCP, 2020).

According to the World Bank, real GDP would decrease by 4\% in 2020. Although few sectors are spared, this contraction is mainly due to the fall in the production of goods and services, reduced exports, the disruption of global value chains, and the decline in tourism due to the closure of borders and measures restricting mobility (World Bank \& United Nations; 2020). The Covid-19 pandemic has had a catastrophic impact on the Moroccan economy in 2020, causing a marked recession, the first since 1995, with a drop of more than $6 \%$ in Gross National Product (GNP) and a government budget deficit of $8 \%$ (World Bank, 2020).

\section{ANALYSIS OF THE IMPACTS OF COVID-19 ON FOOD SECURITY IN MOROCCO}

The multiple effects of this crisis (economic, financial, health, etc.) and the very negative impacts that will follow require us to think of innovative solutions, where human well-being must take precedence over profitability, putting back on the political agenda the importance of efficient and inclusive education and health systems, as well as sustainable modes of agricultural production and consumption (Laborde et al., 2020). These ideas must now be invested in the service of designing models that allow future generations to evolve in an environment that is still livable, despite the immense challenges of climate change (Acuto, 2020). 
Based on the literature review, the evaluation of covid-19 pandemics' consequences on food security may be grouped into agriculture, farms resilience, food demand, food supply, labor regulation, general financial and social outcome, and global alternate issues. (Cranfield, 2020; Darnhofer, 2020; Jámbor et al., 2020; Siche, 2020; Villulla, 2020; Zarei \& Rad, 2020). The evaluation of those covid-19 consequences is carried out primarily based totally on the risk, vulnerability, resilience framework described above.

\subsection{The impact of Covid-19 on agricultural employment}

At the start of the containment in March 2020, the importance of agriculture became clear to everyone: the emergency food stocks built up by households became invaluable, especially as supply disruptions were feared. The population was also able to realize the contribution of agriculture to the provision of employment, at a time when many economic activities had come to a halt in the city. Many workers were forced to return to their villages, and some recovered even a modest income by temporarily employing themselves in agriculture.

This observation applies accurately to agriculture since this sector employs nearly 40 percent of the working population in Morocco but generates only 14 percent of GNP (Haut Commissariat au Plan, 2015). For the agricultural workforce, this means low and unstable wages, given the seasonality of activities, especially in rain-fed production systems. In addition, the balance of power in the sectors is systematical to the detriment of farmers, which limits their income and that of their employees. Even in irrigated areas, studies show that one day of farm work often generates an income of fewer than 9 euros (Sraïri et al., 2018).

This is due to the volume of on-call work required by livestock (daily feeding and care) (Cournut et al., 2018) as well as the difficult mechanization of crops (especially market gardening). In this regard, the emergence of the pandemic has accentuated these economic difficulties, as travel restrictions have hampered the use of hired labor and marketing opportunities for perishable commodities (fruits and vegetables, especially).

Similarly, the decline in purchasing power and the closure of fast-food outlets resulted in lower prices for certain agricultural commodities, including chicken and eggs, adding to the economic woes of the poultry industry. It should also be remembered that the overwhelming majority of agricultural workers do not enjoy any social protection (health care coverage and pension plan), which does not motivate them to remain in the sector. This explains the aspirations of many rural people, including the sons and daughters of farmers, to move to the countryside or to emigrate in search of better living conditions (Bossenbroek et al., 2015). 
On the agriculture side, the cancellation of the Salon de agriculture (SIAM) should cost the segment of cooperatives and economic groups more than $12 \mathrm{MDH}$ of goods with a risk of loss of turnover between $60 \%$ and $80 \%$. And since many small farmers take advantage of promotions during the show to acquire machinery and equipment, the machinery sector could lose between $30 \%$ and $50 \%$ of its turnover.

In addition, the association of producers and exporters of fruit and vegetables (APEFEL) said that exports of fruit and vegetables to the European Union are currently increasing, due to the slowdown in Spanish, Portuguese, and Italian production. Prices are also rising compared to normal market conditions. This increase in demand concerns many products, including tomatoes, zucchini, peppers, and eggplants in the vegetable category and oranges and mandarins in the fruit category. While APEFEL reassures about the continuity of logistics flows, some producers report disruptions in the chain, since most of the export to Europe is by truck.

\subsection{The impact of Covid-19 on food demand}

Demand implies the willingness and ability to pay money for a good or an individual, during a given period. The demand for food has decreased due to and the reduction in the purchasing capacity of although this decrease is still small; the situation could worsen if the pandemic is prolonged due to falling incomes and jobs.

Consumers are greatly changing their grocery shopping habits due to the evolving Covid19 pandemic, also due to growing public awareness that food supply chains, which normally operate largely unfocused and highly efficient, are fragile. With supply chain disruptions and strong instructions in several states on social distancing and a reduced number of grocery stores, circumstances have forced consumers to consider food storage, as well as various food sourcing decisions (Schmidt et al., 2020a). People eat at home, which means more home cooking.

The pandemic has had immediately affected food supply chains. Grocery shops have a skilled dearth of a few staples and sparkling gadgets supply, and lots of farmers with direct income noticed their market closed whilst others have boomed in demand. As marketplace channels had been closed down, inclusive of farmers' markets, eating places, and institutions, farmers have urgently sought different opportunity shops to promote out their perishable goods (Schmidt et al., 2020b). The pandemic, that is jeopardizing human and organizations fitness alike, inclusive of small-and large-scale farms, has led, at the least anecdotally, organizations, farmers, and clients to extrude their version and behavior, withinside the mild of closed eating places and schools, grocery shops depleted directly through clients (Kolodinsky et al., 2020, p.6). 
Cranfield (2020) observed that income consequences as a result of the Covid-19 economic stoop might be a vital aspect affecting purchaser food demand throughout and after the pandemic, and will eventually spark off important distributional problems that necessitate attention whilst comparing the effect of Covid-19. For the Delegation of the European Union in Morocco, it is obvious that, for the foodprocessing sector, the effect of Coronavirus could manifest itself, on the one hand, in the supply of raw materials and inputs, less and less available, and, on the other hand, in the decline of foreign demand.

The 2,000 agro-industrial units present in Morocco could indeed be led to a problem of supply of ingredients and additives, mostly imported. Furthermore, the production lines of Moroccan factories could be disrupted because of the drop in safety stocks of certain semi-finished products, such as fruit concentrate, the basis of industrial juice production and imported mainly from the European Union.

At the same time, and according to the Federation of Fishing Industries (FENIP), some operators note disruption in the logistics and supply chains of raw materials, particularly metal cans for food canning. For fishing, the impact is, at this stage, minimal due to the biological rest period for artisanal fishing.

\section{3. the impact of covid-19 on food supply}

The FAO report on "The State of Food Security and Nutrition in the World 2019" explains that crises that cause price volatility and disruption of food chains are the most important causes of food insecurity. Food supply will be particularly felt in countries that are heavily dependent on commodity imports and/or agricultural exports in general.

The report points out that when dependence on commodity imports increases by 1 percent in one year, it leads to an average increase in undernourishment of 3.8 percent (FAO, 2019).

Despite dependence on imports of certain commodities, the state of food security in Morocco is very satisfactory and does not present significant difficulties. However, pockets of poverty and cases of vulnerability persist. Morocco is among the countries with high poverty rates among those on the African continent, along with Zimbabwe, Mali, Somalia, and Gabon. In the kingdom, the poverty rate even increased between 2019 and 2020, from 17.1 to 19.87, according to data from the Office of the High Commissioner for Planning (HCP), the UN, and the International Monetary Fund.

After updating the data collected from the Ministry of Agriculture, Bank Al-Maghrib has revised the forecast of agricultural value-added for the year 2019 by 130 bps (Bank Al-Maghrib, 2020). As of December 31, 2019, cumulative rainfall recorded a 38\% decrease compared to the previous year (Figure2). 
Figure 2: Evolution of agricultural value-added between 2016 and 2020 Evolution de la VA agricole

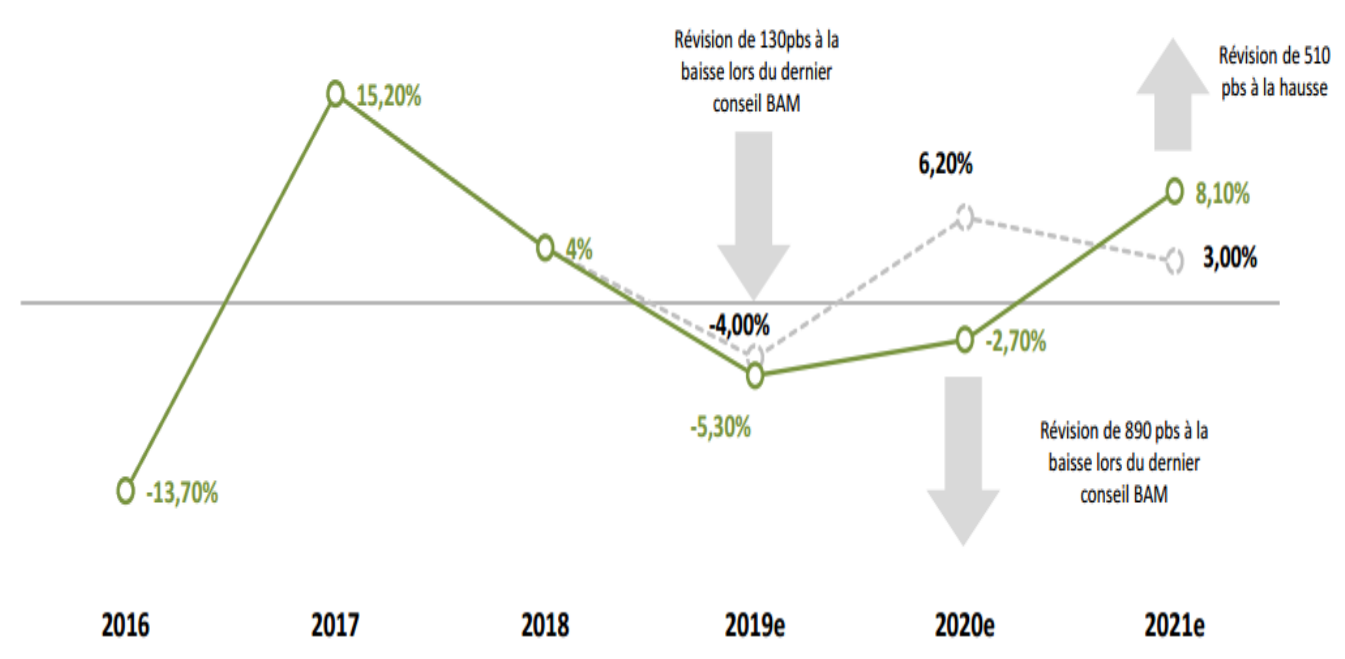

Source: BAM, 2020

In 2020, the last board of the central bank has considerably revised the forecasts of the agricultural added value from $+6.20 \%$ to $-2.70 \%$ and this is mainly due to the forecasts below the normal of the cereal year, namely $40 \mathrm{MQX}$.

Moreover, the rainfall deficit at the beginning of the current campaign has characterized most of the Kingdom's regions may lead to a filling rate of dams for agricultural use of $47.6 \%$ instead of $60.2 \%$ a year ago.

Assuming a return to normal agricultural season (75MQX), agricultural value-added should rebound to $8.10 \%$ in 2021(MAPM, 2021).

The impact of the covid-19 pandemic and the drought has been reflected in the updated forecasts of the main forecasting bodies in Morocco, the Central Bank, HCP and CMC have unanimously revised their GDP growth forecasts for the year 2020 downwards from $2.30 \%$ to $0.80 \%$.

In Morocco, in 2008, the Green Morocco Plan (PMV) has stimulated the emergence of high value-added and high productivity agriculture. Result: The value of agricultural food exports totaled 39.5 billion dirhams (MMDH) for the 2019-2020 agricultural season, an increase of 8\% compared to 2018.

The continuation of agricultural activity in the various packaging and processing units has preserved the export activity, which has achieved positive results under these current exceptional circumstances.

\subsection{The impact of covid-19 on food systems}

According to the FAO, the peri-urban population around cities where containment measures have been adopted has already experienced a decline in demand for food products and disruptions in the supply 
chain as a result of partial closures of fairs and community markets and reduced purchasing power of urban households (FAO, 2021).

The covid-19 may be handled as a catastrophe related to risks and dangers. Though a catastrophe is an apprehension of risk, there may be no universally idea and settlement amongst pupils approximately the size of the risk to be certified as a catastrophe, but covid-19 pandemic may be handled as catastrophe contemplating average bad influences and dangers happened around the arena and the range of deaths totaling to nearly 2 billion.

The result is increased post-harvest losses and food waste, particularly for highly perishable foods (such as fruits, vegetables, meat, and fish) and significant income losses for rural populations, including the main revenues that come from the sale of these products.

An extension of the pandemic could also have an impact on the next production season if labor supply and production capacity are further reduced due to movement restrictions and/or increased VIDOC infections 19 and if access to productive inputs (such as fertilizers, seeds, and pesticides) is hampered by rising international prices and supply chain bottlenecks (Figure 3).

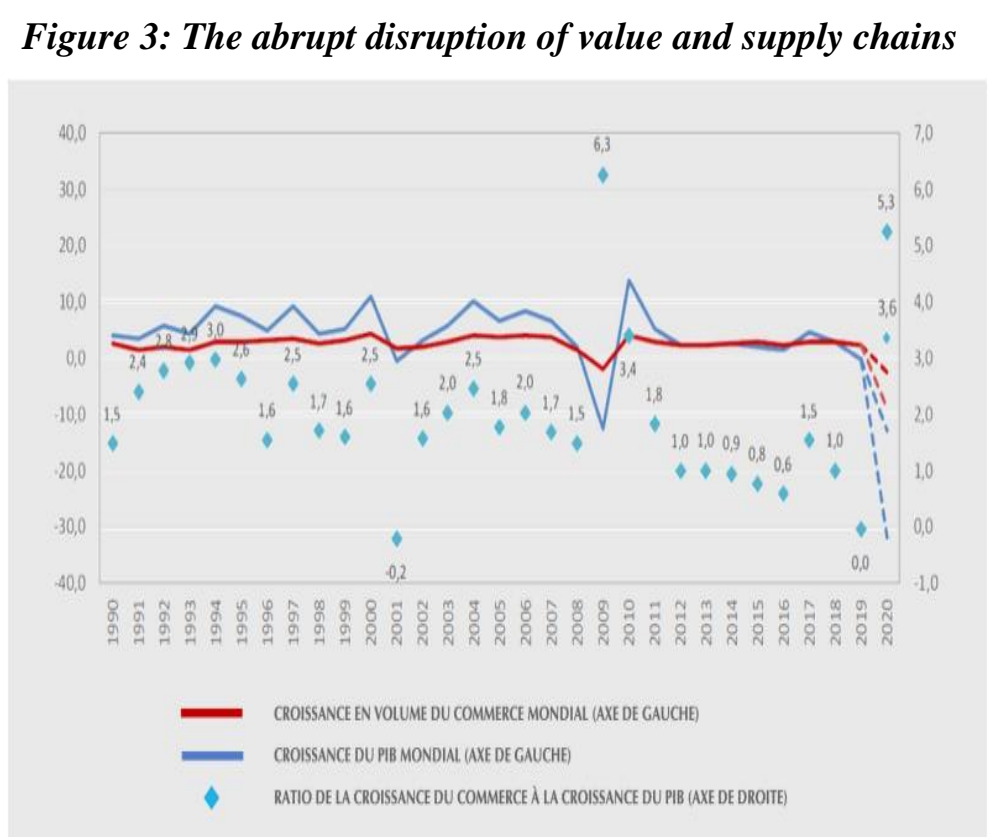

Source: $O M C, 2020$

In addition, voluntary or mandatory market closures, local and international health barriers, and reduced labor in the food supply chain and market transactions could lead to delays in food supply and temporary shortages, with subsequent price increases, particularly in food-deficit areas.

The most affected would-be urban areas, which depend on the food supply of rural agriculture, as well as remote and underserved rural areas such as the southern regions where vulnerability has been 
aggravated by a lack of rainfall useful for agriculture from November 2019 to February 2020, which has reduced the cereal and pulse harvest, and where off-season crops are also affected by significant water stress during their development phase (ARC, WFP, FAO, UNICEF).

\section{THE IMPACT OF COVID-19 ON WORLD FOOD PRICES}

The inflation rate is the growth rate of the consumer price index (CPI), which measures the relative change in consumer prices for a fixed basket of goods consumed by households. A higher value of the inflation rate relative to the base period means that the speed with which prices are rising has increased.

Due to outside dependence, meals protection is precisely connected to global meal charge volatility (Lacirignola, Adinolfi \& Capitanio, 2015). Preferences, expenses, and earnings perform a pivotal position in understanding how calls for meals get affected for the duration of the Covid-19 crisis (Cranfield, 2020). World meals expenses faded for a fourth consecutive month in May, struck through the monetary drop of the coronavirus pandemic which has hampered call for, the United Nations meals enterprise stated (UNFA, 2020). The Food and Agriculture Organization (FAO, 2020) meals charge index, which measures month-to-month adjustments for a basket of cereals, oilseeds, dairy products, meat, and sugar, averaged 162. five factors final month, down $1.9 \%$ on April, it became the lowest month-to-month studying considering that December 2018.

According to World Bank (April 23, 2020) Agriculture charges are now no longer plenty correlated to monetary growth, and witnessed the most effective slight growth withinside the first zone of 2020. Prices are maximum probably to maintain their balance in 2020 ordinary as manufacturing tiers and shares of maximum staple ingredients are at document highs. However, agricultural commodity manufacturing may also revel in disruptions regarding the trade, distribution of inputs, and exertions availability.

At the national level, inflation accelerated slightly during 2020 to 0.7 percent from 0.2 percent in 2019 , the result of a 0.9 percent increase in the food CPI and a 0.5 percent increase in the non-food CPI. An upward turn in consumer prices was observed starting in August 2020, driven mainly by the increase in prices of volatile food products, particularly fruits, vegetables, and edible oils.

This increase in prices following the succession of two years of drought, combined with an increase in the price of agricultural raw materials on the international market, brought the contribution of the food CPI to overall inflation to +0.36 points, instead of -0.5 points in 2019 . At the non-food level, education prices contributed +0.15 points instead of +0.2 points a year ago.

On the other hand, prices of fuels and lubricants contributed -0.35 points instead of -0.07 points in 2019 . Following the effects related to the spread of Covid-19 in most countries in March 2020 manifested by 
an oversupply of oil and a saturation of storage capacity, the price of Brent crude oil had fallen by $67.3 \%$ in April, in annual variation, to $\$ 23.3 /$ barrel, the lowest monthly average level since 2002. From May onwards, prices began to recover, closing the year at $\$ 50 /$ barrel, i.e. an average annual price of $\$ 42.3 /$ barrel in 2020, instead of $\$ 64.3 /$ barrel in 2019.

The consumer price index (CPI) recorded an increase of 2.2\% in July 2021, compared to the same month of the previous year, according to the High Commission for Planning (HCP). this evolution is explained by the increase in the index of food products of $2.8 \%$ and that of non-food products of $1.8 \%$, said the HCP in a note on the CPI of July 2021. Figure 4 shows the evolution of the inflation rate in Morocco over the last ten years, intending to analyze its fluctuation.

\section{Figure 4: The annual inflation rate in Morocco}

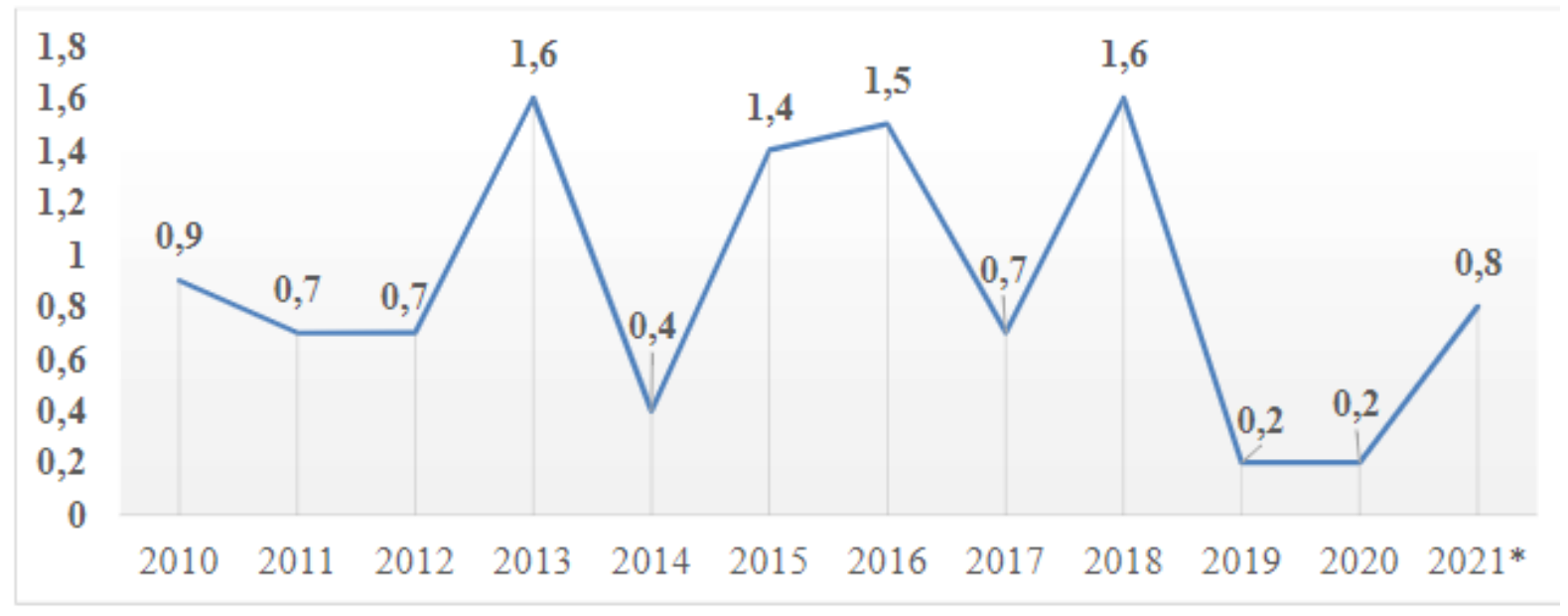

Source: IMF, World economic outlook (October 2020).

The increases in food products observed between June and July 2021 are mainly "Fish and seafood" with $1.3 \%$, "Meat" with $1.0 \%$, "Oils and fats" with $0.9 \%$, "Vegetables" with $0.7 \%$, and "Coffee, tea and cocoa" with $0.3 \%$, the same source notes.

However, prices have decreased by $1.4 \%$ for "Fruit" and $0.3 \%$ for "Mineral waters, soft drinks, fruit juices, and vegetables. For non-food products, the increase has mainly concerned the prices of "fuels" with $3.2 \%$.

The price increases of table oils and other food products such as cereals are due to the increase in the price of raw materials on the international market. The consumption expenditure of table oil represents $1.7 \%$ of the overall index and that of bread and cereals 7.07\%. At the end of February 2021, the world price of sunflower oil and soybeans increased, respectively, by $9.2 \%$ and $25.8 \%$, instead of $+11.2 \%$ and 
$+9.4 \%$ in the whole year 2020. Corn prices rose by $40.9 \%$, compared to $-2.7 \%$ in 2020 , and wheat prices rose by $+13.6 \%$, instead of $+7.8 \%$ for the entire year 2020 . The rise in commodity prices may also extend to red meat. Nearly $87 \%$ of animal feed and fattening is composed of corn, barley, and soybean meal, products that are imported from abroad. Eggs and white meats are also likely to suffer the consequences of this rise in raw materials because, like the red meat sector, poultry feed depends on imported compound products for the most part.

However, the inflationary risks would remain limited in the short term. The rise in the price of imported raw materials will be somewhat mitigated by the appreciation of the dirham against the dollar $(-6.3 \%$ in January 2021, instead of $1.3 \%$ in 2020). For its part, the prospect of a good agricultural year after two successive years of drought and the weak pressures emanating from demand would be likely to keep the inflation rate during 2021 at still moderate levels.

\section{Conclusion}

The Covid-19 pandemic, especially with the various traffic restrictions and prevention measures that resulted worldwide, has had serious consequences on the Moroccan economy, which is among the most open international trade in the world. Added to this is the fact that most Moroccans do not have a guaranteed fixed income, so the drop in income raises fears for a major food crisis.

The Covid-19 pandemic revealed the crucial contributions of agriculture to the daily life of citizens, such as the supply of food, the maintenance of territories, the creation of millions of jobs, etc. These functions were maintained thanks to the measures taken by the authorities for the continuity of agricultural activities during the containment, which was not possible for sectors such as tourism or events. The pandemic did, however, expose the structural weaknesses of Morocco's agricultural sector, as citizens became aware of the huge quantities of imported food products.

The Kingdom is reaping the fruit of strategic choices made for decades, which began with the visionary policy of dams in the early years of Independence and be strengthened in 2008 by the Green Morocco Plan (GMP), which brought agriculture into the era of modernization and massive private and public investment.

The study concluded that the spread of the Covid 19 pandemic has ensued several negative effects, which have directly and indirectly threatened food security. First, the Covid 19 pandemic severely affected the Moroccan agricultural sector which contributes significantly to GDP, due to suspension of agricultural activities, restriction of trade in agricultural commodities, and agricultural labor. 
Second, Covid 19 has primarily affected food imports due to the food importation from European countries in particular, due to the preemptive measures undertaken by some European countries that suspended all sorts of food exports to prepare for any scenario that might threaten their food security if the pandemic lasts longer, which would ultimately put food security of importer countries under a serious threat.

Third, the Covid 19 pandemic has influenced agricultural commodities sales, as the lockdown measures involved most buyers of these commodities such as restaurants, hotels, schools, and major shopping centers. unstable agricultural products (such as some types of vegetables and fruits) have also been damaged, due to movement restriction, which inflicted significant losses to the producers of these products. Fourth, the Covid 19 have impacted food supply chains, as the shutdown and closing of some stores severely disrupted the supply chain (transportation, storage, and distribution), resulting in food insufficiency in many far areas.

On the other hand, COVID-19 exposed the gaping vulnerabilities of global food systems to shocks of this nature and recalled that food is not a product like any other. The remarkable dynamic of solidarity and community action is nevertheless one of the most striking reactions to this crisis. Communities have come together to fill gaps in the system and help those in need.

Based on findings, and to reduce the negative impacts of the pandemic of Covid 19 or any type of pandemic that may appear in the future on food security, we recommend the following: (1) Conducting the whole set of studies to identify the organizational, economic, and environmental hurdle in the agricultural sector, livestock and poultry farmers, and then seek to find practical solutions, (2) A gradual and calculated import reduction of food commodities, especially grains, and dedicating the best possible efforts on bringing about effective strategies to reach food self-sufficiency to reduce dependency, and finally (3) the Covid-19 pandemic should be seen as an opportune time to objectively assess past and current public policies, including the VMP, and to identify sustainable ways forward for the agricultural sector.

\section{REFERENCES}

[1] Bank Al Maghrib, revue de la conjoncture économique 2020/ http://www.bkam.gov.ma/Publicationsstatistiques-et-recherche/Documents-d-analyse-et-de-reference/Revue-de-la-conjonctureeconomique/Revue-de-la-conjoncture-economique-2020

[2] Barichello R., (2020). «The COVID-19 pandemic: Anticipating its effects on Canada's agricultural trade». In Canadian Journal of Agricultural Economics, 68. https://doi.org/10.1111/cjag.12244 
[3] Cranfield J., (2020). «Framing consumer food demand responses in a viral pandemic». In Canadian Journal of Agricultural Economics, 68. https://doi.org/10.1111/cjag.12246

[4] Deaton B.J., \& Deaton B.J., (2020). «Food security and Canada's agricultural system challenged by COVID-19». In Canadian Journal of Agricultural Economics, 68. https://doi.org/10.1111/cjag.12227

[5] FAO, (2020a). "COVID-19 and the impact on food security in the Near East and North Africa: How to respond?", Food and Agriculture Organization of the United Nations, Cairo. https://doi.org/10.4060/ca8430en

[6] FAO, (2020b). "World Food Situation". Food and Agriculture Organisation. Available online: http://www.fao.org/worldfoodsituation/foodpricesindex/en/ (Visited: 06 June 2020)

[7] Kerr W.A., (2020). «The COVID-19 pandemic and agriculture - Short and long-run implications for international trade relations». In Canadian Journal of Agricultural Economics, 68. https://doi.org/10.1111/cjag.12230

[8] Kolodinsky J., Sitaker M., Chase L., Smith D., \& Wang W., (2020). «Food systems disruptions: Turning a threat into an opportunity for local food systems». In Journal of Agriculture, Food Systems, and Community Development, $9, \mathrm{n}^{\circ} 3$, pp 5-8.

[9] Lacirignola C., Adinolfi F., \& Capitanio F., (2015). «Food security in the Mediterranean countries». In New Medit, vol. 14, $\mathrm{n}^{\circ}$ 4, pp 2-10.

[10] Richards T.J., \& Rickard B., (2020). «COVID-19 impact on fruit and vegetable markets». In Canadian Journal of Agricultural Economics, 68. https://doi.org/10.1111/cjag.12231

[11] Seleiman M.F., Selim S., Alhammad B.A., Alharbi B.M., \& Cezar Juliatti F., (2020). «Will novel coronavirus (Covid-19) pandemic impact agriculture, food security, and animal sectors? ». In Bioscience Journal, vol. 36, $\mathrm{n}^{\circ} 4$, pp 1315-1326.

[12] Schmidt C., Goetz S.J., Rocker S.J., \& Tian Z., (2020a). «Google searches reveal changing consumer food sourcing in the COVID-19 pandemic». In Journal of Agriculture, Food Systems, and Community Development, vol. 9, $\mathrm{n}^{\circ} 3$, pp 9-16.

[13] Siche R., (2020). «What is the impact of COVID-19 disease on agriculture? ». In Scientia Agropecuaria, vol. $11, \mathrm{n}^{\circ} 1, \mathrm{pp} 3-6$.

[14] Willy D.K., Diallo Y., Affognon H., Nang'ayo F., Waithaka M., \& Wossen T., (May 2020). "COVID-19 Pandemic in Africa: Impacts on agriculture and emerging policy responses for adaptation and resiliencebuilding". The Technologies for African Agricultural Transformation (TAAT) Policy Compact. Working Paper No. WP01/2020. Available online: https://www.aatf-africa.org/wpcontent/uploads/2020/06/TAATPolicy-Working-Paper-on COVID19_FINAL-for-Dissemination_May-2020.pdf (Visited: 01 June 2020).

[15] World Bank, (April 23, 2020). "Most Commodity Prices to Drop in 2020 As Coronavirus Depresses Demand and Disrupts Supply". Available online: https://www.worldbank.org/en/news/pressrelease/2020/04/23/most-commodity-prices-to-drop-in-2020ascoronavirus-depresses-demand-and-disrupts-supply (Visited: 11 May 2020).

[16] Zurayk R., (2020). «Pandemic and food security: A view from the Global South». In Journal of Agriculture, Food Systems, and Community Development, vol. 9, n³, pp 17-21. 
[17] Sraïri MT, Chatellier V, Corniaux C, Faye B, Aubron C, Hostiou N, et al. 2019. Durabilité du développement laitier : réflexions autour de quelques cas dans différentes parties du monde. INRA Productions Animales 32: 339-358. https://doi.org/10.20870/productions animales.2019.32.3.2561.

[18] Acuto M. 2020. Covid-19: Lessons for an urban(izing) world. One Earth 2: 317319. https://doi.org/10.1016/j.oneear.2020.04.004.

[19] Bossenbroek L, Van der Ploeg JD, Zwarteveen M. 2015. Broken dreams? Youth experiences of agrarian change in Morocco's Saïss region. Cahiers Agricultures 24(6): 342-348. DOI: 10.1684/agr.2015.0776.

[20] Cournut S, Chauvat S, Correa P, Dos Santos Filho JC, Dieguez F, Hostiou N, et al. 2018. Analyzing work organization by the Work Assessment Method: a meta-analysis. Agronomy for Sustainable Development 38: 58.

[21] Laborde D, Martin W, Swinnen J, Vos R. 2020. Covid-19 risks to global food security. Science 369: 500502.

[22] Zarei, M., \& Rad, A. K. (2020). Covid-19, challenges, and recommendations in agriculture. Journal of Botanical Research, 2(1). 